\title{
Multilateral Engagement of North Korea: An Assessment of the Six-Party Talks and the ASEAN Regional Forum
}

\author{
Ming Hui Tan
}

\begin{abstract}
North Korea's unchecked missile and nuclear program is one of the most pressing global security concerns. This article evaluates the multilateral engagement efforts that have been pursued by regional stakeholders, specifically assessing the SixParty Talks vis-à-vis the ASEAN Regional Forum (ARF), and explaining why these multilateral efforts have failed to resolve the nuclear crisis. Given the poor performances of these two multilateral platforms, this article seeks to assess the feasibility and policy implications of defusing the longstanding nuclear crisis through multilateral engagement. Despite stalling and a myriad of obstacles, the Six-Party Talks has a better chance than the ARF at curbing the nuclear crisis. At best, the ARF can contribute by playing a complementary role by helping deescalate tensions or cultivating better diplomatic ties.
\end{abstract}

Keywords North Korea, nuclear crisis, multilateralism, engagement, Six-Party Talks, ASEAN Regional Forum

\section{Engagement through Multilateralism}

In his article published in the 1994 March-April issue of Foreign Affairs, then U.S. National Security Advisor Anthony Lake labeled North Korea as one of five "backlash" regimes in the post Cold War period (Lake 1994, 45). North Korea has also been frequently called a "rogue" state, and more recently an "outlier" state, due to its numerous belligerent actions as well as its ballistic missile and nuclear development program. In fact, North Korea's unchecked missile and nuclear program is one of the most persistent and pressing global security concerns.

North Korea has accelerated its missile development program since Kim Jong-un took over the reigns in 2011. He has ordered more weapons tests than his father and grandfather combined, and has continued to carry out missile launches despite its neighbors' protests and new United Nations (UN) sanctions. On July 4, 
2017, North Korea conducted its first test of an intercontinental ballistic missile (ICBM), which is believed to be capable of reaching the mainland United States. Although most analysts are unconvinced that the nuclear device tested in January 2016 was a hydrogen bomb, as was claimed by Pyongyang, two things remain clear: the country's alarming nuclear ambitions, and the steady advancement of its nuclear weapon and missile program. Even if North Korea has no intention of using these weapons against its neighbors, the development of its nuclear arsenal poses a great security threat to the non-proliferation regime. A nuclear-armed North Korea could potentially trigger a nuclear arms race in the region, and it would be catastrophic if Pyongyang were to export its nuclear materials and expertise to other rogue states or terrorist groups.

In reaction to these recent developments, many watchers and experts have pointed to the failure of former U.S. President Barack Obama's policy of "strategic patience," calling for the resumption of active engagement with North Korea, particularly through the Six-Party Talks framework (Green 2016). This article seeks to examine and evaluate the multilateral engagement efforts that have been pursued by regional stakeholders to resolve the North Korean nuclear crisis. Specifically, the article will assess the Six-Party Talks vis-à-vis the ASEAN Regional Forum (ARF). Through this assessment, this article seeks to understand why these multilateral efforts have ultimately failed to curb the crisis. Given the poor performances of the two multilateral platforms, this article seeks to examine the feasibility of multilateral engagement in defusing the longstanding nuclear crisis and the policy implications of the findings.

Robert O. Keohane defines multilateralism as "the practice of co-ordinating national policies in groups of three or more states, through ad hoc arrangements or by means of institutions" (Keohane 1990, 731). Much has been written on the nature and limitations of multilateral institutionalization in the region. For instance, Yoshinobu Yamamoto provides a theoretical analysis of institutionalization with a focus on the Northeast Asia region (Yamamoto 2008, 21-42). He defines institutions as "patterned behavior among the members of a group," and suggests "if nations repeat the same or similar behavior in relations to each other ... an institution exists" (ibid., 22). Yamamoto highlights four types of institutions: Type $\mathrm{A}$ as exclusive and competitive, Type $\mathrm{B}$ as exclusive but non-competitive in nature after the Cold War, Type $\mathrm{C}$ as inclusive but competitive, and Type $\mathrm{D}$ as inclusive and non-competitive (ibid., 24-25). According to him, the Six-Party Talks belongs to Type $\mathrm{C}$ and the $\mathrm{ARF}$ is a Type $\mathrm{D}$ institution, asserting that the former has the potential to transform into a Type D, which to him is the "ideal" type of institution (ibid., 26). However, he also admits that the ARF has "played only marginal roles in Northeast Asian security affairs" (ibid., 36). This article seeks to continue this discussion by asking whether or not the ARF, a Type D institution, is indeed "ideal" and more effective in curbing security issues in the region vis-àvis the Six-Party Talks. 
Upon closer examination, however, this article posits that the Six-Party Talks, despite its failings, has more short-term potential and would be more effective at curbing the nuclear crisis than the ARF, if the former resumes. Overall, this article shows that both have little chance at achieving denuclearization on the Korean Peninsula. Nevertheless, despite stalling and a myriad of obstacles, the Six-Party Talks still has a better chance than the ARF at curbing the nuclear crisis and restraining the DPRK. At best, the ARF can contribute by playing a complementary, but secondary, role to the Six-Party Talks. At the same time, a closer understanding of North Korea's motivations, on top of the lessons learnt from the relatively successful case study of Iran, reveal that the Six-Party Talks needs to increase the stakes and opportunity costs for the DPRK for the efforts to have a greater chance of success.

The structure of this article is as follows: it will first review existing literature relating to the topic, which includes an overview of the arguments that support engagement as the best policy option to resolve the North Korean nuclear crisis. The following section offers a critical assessment and comparative analysis of the structural designs and effectiveness of the ARF and the Six-Party Talks. Next, the article will discuss the motivations of North Korea and provide a brief examination of the the case study of Iran which has been hailed a relatively successful example of a multilateral solution, drawing useful lessons and policy implications for the Korean Peninsula. Finally, the article will conclude by highlighting some complementary policy options that may contribute to safeguarding peace and security in the region.

\section{The Case for Engagement}

As the nuclear crisis on the Korean Peninsula remains unresolved, the polemical debates on the best policy options continue. The "hawk" camp tends to prefer coercive methods, such as tougher economic sanctions, believing that negotiation and compromise will only result in the rewarding of bad behavior and allow North Korea to buy time to develop its nuclear program. Despite the limitations of multilateral engagement efforts in curbing North Korea's nuclear ambitions, the "dove" camp asserts that engagement is the best policy option, as it can help persuade North Korea to give up its nuclear weapons if the regime is promised and given positive incentives. Eventually, engagement would socialize North Korea and lead it to become a "normal" member of the international community.

Victor Cha and David Kang provide a comprehensive debate on engagement strategies towards North Korea (Cha and Kang 2003). Both conclude that "under most conditions ... the default policy toward North Korea is engagement" (ibid., 4), even though Kang advocates more open engagement while Cha favors a more "hawkish" approach of conditional engagement. Jacques L. Fuqua Jr. promotes 
a longer-term approach of constructive engagement, calling on Washington to pursue a policy of "asymmetric economic statecraft," which is much closer to the positions of China and South Korea (Fuqua 2007). He suggests that a greater dependence on economic outreach would not only curb North Korea's belligerent behavior but also facilitate soft-landing if reunification were to occur.

Chung-In Moon asserts that the North Korean nuclear crisis could be resolved in a peaceful manner through the resumption of the Six-Party Talks (Moon 2013, 237). He urged the Obama administration to learn from the merits of the Clinton administration's Agreed Framework model and avoid the issues that complicated the Bush administration's efforts (ibid., 236). Sung Chull Kim and David Kang also posit that "engagement is a viable alternative to coercive strategies for inducing North Korean cooperation" (Kim and Kang 2009, 14). According to them, Washington should strive to lessen North Korea's siege mentality by distancing any negotiating platform from the legacy of the Korean War and by normalizing relations with Pyongyang, thereafter creating a more effective Six-Party Talks framework (ibid.). They also highlight that an agreement reached by multilateral engagement is more effective that bilateral ones, as long as the member states coordinate their policies (ibid., 9-11).

In recent years, the pro-engagement camp has criticized the ineffectiveness of the Obama administration's policy of "strategic patience," which comprises of non-negotiation with North Korea until it shows evidence of adhering to earlier agreements and maintaining sanctions while waiting for the regime to change instead of rewarding its bad behaviors. Instead, they argue that the United States should resume active engagement. For example, Hazel Smith suggests that "strategic patience [has] morphed into paralysis as North Korea became a de facto nuclear armed state" (Smith 2015, 326). Also, Jong Kun Choi points to the "perils" of strategic patience with North Korea, positing that anticipating a collapse of the current North Korean regime will do little to denuclearize the peninsula (Choi 2016, 57-72). He argues that Pyongyang is highly unlikely to surrender, and even if the current regime does eventually collapse, there is no guarantee that the replacement government would give up its nuclear arsenal easily. According to Choi, there is an urgent need to re-engage North Korea as "erecting a wall of silence in the name of strategic patience will only exacerbate the present danger and render it uncontrollable" (ibid., 66).

On the whole, these scholarly analyses highlighted above provide strong reasons why pursuing active engagement with North Korea, especially through multilateral platforms, is necessary to persuade the rogue state to modify its belligerent behavior and give up its nuclear arsenal. This article hopes to further contribute to the existing literature by closely examining the two existing multilateral tools available to engage the DPRK, namely the ARF and the SixParty Talks, and to understand why they have yet to contain the North Korean nuclear quagmire. Additionally, a comparison of both the Type C and Type D 
multilateral efforts is useful as we can draw valuable structural and policy lessons from their individual strengths and weaknesses. At the same time, studying both the ARF and the Six-Party Talks together will also clarify whether these platforms could be complementary and if they could work in tandem to forestall a nuclear nightmare in the region. Finally, this article also seeks to provide an update of the feasibility and policy implications of continuing with such engagement efforts in the light of recent developments on the Korean Peninsula.

\section{The ASEAN Regional Forum Versus the Six-Party Talks}

\section{Beginnings}

The ASEAN Regional Forum was established in 1994 as a region-wide forum that facilitates security dialogue following the Nakayama proposal. It was viewed as a huge breakthrough in the Asia-Pacific region since multilateral institutions were previously "non-existent and seen as difficult to achieve" (Ashizawa 2004, 149). In the immediate post-Cold War period, regional tensions were on the rise and the region had been frequently disturbed by multiple territorial disputes in the South China Sea and the East China Sea, the continued division of the Korean Peninsula, and the ongoing tensions over the Taiwan question (Glosserman 2010, 40). The Asian governments feared an impending arms race, which would create security dilemmas leading to further escalation of existing tensions. Therefore, ASEAN recognized the urgent need for a multilateral solution, which included China, Russia, and Vietnam (ibid.). The ARF currently consists of twenty-seven participants, including all six members of the Six-Party Talks. From the onset, the nuclear crisis on the Korean Peninsula has been on the agenda of the ARF, with the Chairman's statement of the inaugural meeting stating, "Bearing in mind the importance of non-proliferation of nuclear weapons in the maintenance of international peace and security, the Meeting welcomed the continuation of the U.S.-DPRK negotiation and endorsed the early resumption of the inter-Korean dialogue" (ASEAN Regional Forum 2007, 3). Since then, developments on the Korean Peninsula have been included in all Chairman's statements of ARF meetings.

The Six-Party Talks was set up in 2003 specifically to deal with North Korea's weapons and its nuclear development program through multilateral negotiations. The United States preferred an inclusive multilateral approach to bilateralism because other players, namely China, Russia, Japan, and South Korea, also have vested interests in the nuclear crisis. Their cooperation was deemed necessary for the negotiations to be comprehensive and successful (Buzynski 2013, 53). At the same time, the Bush administration was heading into an armed conflict with Iraq and acknowledged the impracticalities of resolving the North Korean issue through another military confrontation (ibid., 59). 


\section{Designs}

Meant as an all-inclusive and non-competitive multilateral institution (Yamamoto 2008), the ARF stems from the concept of a cooperative security regime. Conflicts are to be resolved through continuous dialogue while the use of force is not an option. When a country acts as a norm-breaker, the rest of the members exert peer pressure in order to socialize the former's behavior instead of employing coercive methods. The ARF has embraced "the ASEAN Way" of non-interference in domestic affairs and decision-making through consensus to prevent the major powers from asserting their will at the expense of smaller states (Solingen 2005, 36). This means that decisions are only implemented in a "voluntary nonbinding way" (ibid.). ARF's design is mainly based on the goals of confidence building, preventive diplomacy, and conflict resolution. However, the ARF has seen minimal results in its second and third goals. Kim and Kang define such a design as "unconditional engagement," whereby "available incentives whose cumulative effects ultimately transform the target state's policy preferences as well as its behavior" (Kim and Kang 2009, 5).

In contrast, the Six-Party Talks follows what Kim and Kang refer to as "conditional engagement," which is "accompanied by specific conditions and corresponding incentives that may affect the target state's calculations about cost and benefits" (ibid., 6). In this type of engagement, the stakeholders highlight the potential incentives or punishments, also known as "carrots and sticks," through a series of negotiations in order to pressure, persuade, and ultimately modify the target state's decisions and behaviors. Kim and Kang explain further by referring to the Six-Party Talks as a type of "staged engagement," which "involves a sequence wherein the engaging state would offer incentives in phases in response to the target state's cooperative acts" (ibid., 7). According to them, "the February 13 agreement in 2007 at the Six-Party Talks has as its framework this type of staged engagement: the provision of fifty thousand tons of heavy-oil aid in response to the shutdown of nuclear facilities; the sending of nine hundred fifty thousand tons of heavy-oil aid as compensation for declaration of all nuclear programs and disablement of the facilities" (ibid.).

\section{Effectiveness of the ASEAN Regional Forum}

The inclusion of North Korea as a member of the ARF in July 2000 was welcomed as a positive development (Hughes 2010, 65). In fact, the ARF is now the only regional security institution that includes the DPRK as a regular participant even when tensions are high. Since 2000, the issues surrounding the divided Korean Peninsula, which includes North Korea's missile and nuclear development programs, have been major items on the agenda due to the United States and Japan's proactiveness in raising them (Yuzawa 2010, 83). Both countries have tried to "garner support from other regional countries to bring international 
criticism to bear on North Korea's development of missiles and nuclear weapons" through the forum (ibid., 84). For instance, when North Korea conducted its missile launch and nuclear test in 2006, Japan rallied for a critical statement to be issued against Pyongyang (Yuzawa 2007, 141-149). According to the Chairman's statement for the Thirteenth ARF meeting on July 28, 2006, "most ministers expressed concern over the test-firing of missiles by the DPRK on 5 July 2006 and believed that such tests could have adverse repercussions on peace, stability and security in the region. The Ministers noted the unanimous adoption of the UN Security Council resolution 1695 on 15 July 2006 and the rejection of this resolution by the DPRK. The Ministers urged the DPRK in this regard to reestablish its moratorium on missile testing" (ASEAN Regional Forum 2007, 431).

Nevertheless, both Washington and Tokyo have faced difficulties in sustaining interest and enthusiasm at the forum due to the "considerable slowness of [its] development" (Ashizawa 2004, 267). Takeshi Yuzawa describes how Japan's disappointing experiences in the ARF, arising from the lack of meaningful progress in cooperative security measures and its failure to address its own security concerns, have led to Japan to regard it as a mere "talking shop" (Yuzawa 2005, 463-497). In fact, the ARF's adherence to the ASEAN principle of consensual decision making, inclusiveness, and non-interference mean that the effectiveness of the forum is restricted by its lowest common denominator. Yuzawa correctly highlights that North Korea's admission has "actually prevented the ARF from initiating a serious discussion on the issue" as the ASEAN way of passing over and not directly dealing with contentious security issues was applied in order to avoid tensions between members (ibid., 477-478). For example, the July 2010 Chairman's statement of the Seventeenth ARF only expressed "deep concerns" over the March 2010 sinking of the Cheonan, a South Korean naval vessel, and failed to condemn or even name North Korea as the aggressor (ASEAN Regional Forum 2010b). The Yonhap News Agency suggests that this omission of blame was done out of deference to the DPRK (Yoo 2010).

Besides, the ARF's critical statements against North Korea's nuclear program have had very little influence (Yuzawa 2010, 86). For example, when the foreign ministers of several countries condemned the nuclear test and missile launches by the DPRK during the Sixteenth ARF Meeting, the latter simply responded that they "did not recognize and totally rejected the UNSC Resolution 1874 which has been adopted at the instigation of the United States," and "briefed the Meeting ... that the ongoing aggravated situation on the Korean Peninsula is the product of the hostile policy of the United States against her, and stated that the Six-Party Talks have already come to an end" (ASEAN Regional Forum 2010a, 298).

\section{Effectiveness of the Six-Party Talks}

At the initial stages, the Six-Party Talks did see some positive developments. In September 2005, Pyongyang made a promise to end its nuclear weapons 
program and to allow international inspections of its nuclear facilities in return for security and economic incentives. At that time, the September 19, 2005 Joint Statement was regarded as a breakthrough in the diplomatic process between the United States and North Korea as the two countries had been mired in a stalemate since 2003 when the latter announced its withdrawal from the Treaty on the Non-Proliferation of Nuclear Weapons (NPT) (Kahn 2002). Even though the terms of the agreement were left broad and unspecific, it "marked the first concrete agreement among the six parties" (Kwak and Joo 2007, 2). In addition, during the fifth round of the Six-Party Talks in 2007, the six countries managed to reach another agreement whereby the DPRK agreed to shut down its main reactor at Yongbyon in return for heavy fuel oil. The shutdown of the Yongbyon reactor in July and the subsequent disablement process were regarded as one of the first major successes of the member countries' negotiating efforts with North Korea. Similar positive assessments were given to North Korea's belated official declaration of its nuclear assets in June 2008.

However, the multilateral platform eventually failed when North Korea pulled out of the talks in 2009 as a response to condemnation from the UN over a rocket launch. The DPRK claimed that they had only launched a communications satellite, and that it was within its sovereign right to pursue satellite technology and a peaceful space program. Thereafter, North Korea announced its intentions to reactivate its nuclear development program. On the whole, the Six-Party Talks framework proved to be unsustainable in the long-run because its effectiveness was impeded by a myriad of complications, including a misalignment of strategic interests and agendas, great power competition, and partisan politics.

A close examination of the diverse strategic interests and approaches towards the Six-Party Talks reveals a serious lack of unity and coordination, on top of an inherent element of competitiveness within the member countries' dynamics. While the five states had the common goal of North Korea's nuclear disarmament, the United States and Japan pursued a conditional, more coercive approach whereas China, Russia, and South Korea under the Roh administration favored an unconditional approach of engagement. As Buszynski $(2013,15)$ explains, "from the start, unity was absent and though there were valiant attempts to bring about agreement between the parties, their disparate interests would not allow it". Kim and Kang $(2009,8)$ also correctly highlight that engagement with North Korea requires diplomacy on three levels, which encompasses "domestic politics concerning DPRK, bilateral relations with DPRK, and multilateral relations in the Six-Party Talks." In actuality, all parties involved seemed more concerned about their own strategic agendas and domestic interests than the denuclearization of the Korean Peninsula.

In fact, only the United States made the "complete, verifiable and irreversible denuclearization" (CVID) of the DPRK its clear goal and priority from the beginning. For China, Russia, and even South Korea who is a U.S. ally, participation 
in the Six-Party Talks was tied to their long-term strategic calculation of maintaining their interests on the Korean Peninsula and influence over the North, meaning that they were not wholeheartedly supporting the U.S. stance during the negotiations (ibid., 18-19). China's foremost interest was in the prevention of a collapse of the Kim regime. Sharing a border with the DPRK means that a collapse is likely to set off a refugee crisis in China, creating economic and social disorder (Gui 2013, 109). Furthermore, Gui Yongtao suggests that there is a lack of mutual trust between China and the U.S. due to their differences over Taiwan and Tibet, amongst other issues in the Asia-Pacific (ibid.). As a result, China favors North Korea as a buffer zone against U.S. troops stationed in South Korea and Japan. It is also not within Chinese strategic interest to have the North and the South unified under a regime that is democratic and potentially pro-U.S. (ibid., 112). Russia's priority was to stay relevant as a power in Northeast Asia and prevent the United States from taking military action against North Korea that could seriously destabilize its periphery (Buszynski 2013, 38). The different approaches and diverse strategic interests created much tension during the negotiating rounds, and this allowed the DPRK to consistently retain strong support from China and Russia. The two regional powers also formed a coalition with South Korea under the Roh administration to check U.S. power and to pressure it to offer positive incentives to Pyongyang, as they perceived that the latter had a "propensity to resort to force" (ibid., 72).

According to Kuniko Ashizawa, Japan's contributions to the Six-Party Talks were "minimal" as "few noteworthy proposals or suggestions came from the Japanese government in order to make progress ... and Tokyo undertook no substantial actions to bring North Korea back to the talks when deadlocked" (Ashizawa 2006, 420). Furthermore, she highlights that the Japanese government had "conspicuously sought to bring up issues beyond the North's nuclear programme," such as the issue of abductions of Japanese citizens by the DPRK (ibid., 421). In fact, the Japanese representatives had adopted a "no tolerance policy" towards the abduction issue, and its resolution became a precondition for the provision of economic aid to and normalization of ties with the DPRK (Bae and Kim 2009, 84). Japan also pushed for the removal of North Korea from the U.S. State Department's terrorism list to be subjected to the resolution of the abduction issues (Pritchard 2007, 86). In addition, the South Korean government changed its approach towards North Korea and the Six-Party Talks in 2007 because of partisan politics. The administration led by the newly elected President Lee Myung Bak immediately reversed the previous two administrations' policy of unconditional engagement (Kim and Kang 2009, 13), as the new President sought to distance himself from the previous decade of Sunshine Policy and took a more pro-U.S. stance.

The consistency of U.S. policy towards the Six-Party Talks was also disrupted by the presence of partisan politics in Washington. Negotiations were stalled for 
eighteen months immediately after the release of the landmark Joint Statement of September 2005 when the Bush administration accused Pyongyang of manufacturing high-quality counterfeit one hundred dollar bill "supernotes" (Pritchard 2007, 128). The U.S. Treasury Department also ordered a freeze of the assets of North Korean companies suspected of proliferating weapons of mass destruction (WMDs) and imposed sanctions on Banco Delta Asia, a Macau bank suspected of laundering money on behalf of the DPRK (ibid., 129). Even though the United States maintained that these financial issues were separate from the Six-Party Talks negotiations, the DPRK interpreted the actions as the United States reneging on its promises and commitments in the Joint Statement. According to Haksoon Paik, the political clout of the neoconservatives and hardliners in the United States meant that they were able in "entrap" pro-negotiators and prevent the implementation of the statement by raising the financial issues (Paik 2013, 190-191). Similarly, Pritchard asserts that the neoconservatives, who were opposed to "meaningful engagement" with the DPRK and sought regime change instead, had captured control over the U.S. North Korea policy by 2005 (Pritchard 2007, 131). He further points out that pursuing a resolution of the nuclear crisis through negotiations would be futile if the United States is not prepared to normalize relations with the DPRK and accept that the Kim regime would remain in power (ibid., 141).

\section{Comparative analysis}

At first glance, the ARF seems to have a better chance at curbing the nuclear crisis, as it remains the only forum attended regularly by the DPRK in spite of rising tensions. However, upon closer analysis, this article argues that the SixParty Talks still has more potential than the ARF, especially in the short run, in dealing with the nuclear quagmire on the Korean Peninsula. Due to the consensus principle and policy of non-interference inherited from the ASEAN way, the ARF has been underperforming and is unable to reach its potential in terms of preventing and resolving regional tensions in a quick and effective manner. With a large membership of twenty-seven states, negotiation and decision-making can become an extremely cumbersome process since each participant has veto power.

Overall, the ARF prefers a long-term confidence building and socializing approach, stressing conflict avoidance amongst its members. This gradual, non-confrontational approach accounts for its longevity in the region, but also contributes to its ineffectiveness and weaknesses in terms of decision-making and responsiveness to shocks. In the long run, there is some potential that DPRK could be gradually socialized into becoming a normal member of the international community, as there are positive signs that it has taken a more constructive role in the forum in recent years. Rodolfo Severino highlighted that North Korean representatives have been participating more actively and spontaneously in the discussions, compared to their initial meetings when they 
merely read from prepared scripts (Severino 2009, 26). At the present moment, however, the ARF only remains useful as a meeting point for North Korea and the rest of the international community, on top of its long term goal of contributing to the alleviation of security dilemmas through dialogue and improving mutual understanding.

On the other hand, the Six-Party Talks is meant to be an issue-focused and purpose-driven arrangement, which has more potential to handle the nuclear problem in a quick and decisive manner. Nevertheless, future prospects of the Six-Party Talks remain unclear. Since 2009, the talks have yet to resume and the North Korean nuclear problem has not seen any positive development. From the perspectives of the United States and Japan, North Korea's numerous provocative actions point to Pyongyang's unwillingness to make any kind of reasonable concessions and they prefer to avoid rewarding the DPRK's bad behavior with positive incentives. On the other hand, China, who served as the facilitator of the talks, has repeatedly called for all parties to return to the negotiating table. On the whole, the misalignment of the member states' agendas continues to prevent the resumption of the talks. The DPRK set new preconditions for returning to the talks in 2010, insisting on the removal of UN sanctions and the conclusion of an armistice to end the Korean War officially (Kwak 2014, 17). However, the other five parties want North Korea to first return to the talks and commit to the denuclearization process before a peace treaty and the removal of sanctions could be discussed (ibid., 18). The attachment of the diametrically opposed preconditions by both sides means the Six-Party Talks remains on life support, and one side would have to give in before talks can be resumed.

Before the Six-Party Talks resumes, the ARF will continue to play a key role in facilitating bilateral meetings for North Korea with the rest of the international community, even though its impact on denuclearization may be minimal. At best, the ARF can continue to serve as a convenient outlet for officials, especially from the United States, Japan, and South Korea, to improve their relationships and to meet informally with their North Korean counterparts (Glosserman 2010, 45). For example, then Foreign Minister of Japan, Yohei Kono, was able to meet with the North Korean Foreign Minister, Paek Nam-sun, at the Seventh ARF Ministerial Meeting. It was a significant development for Japan-North Korea relations since it was "the first ever bilateral foreign ministerial meeting between the two countries" (Yuzawa 2005, 476-477). Even though ARF's bilateral meetings are usually short and ceremonial in nature (Katsumata 2009, 135), both the United States and Japan have managed to use such meetings to encourage Chinese and Russian participation in their collaborative diplomatic efforts to solve North Korean issues including the Korean Peninsula Energy Development Organization (KEDO) and the Six-Party Talks (Yuzawa 2010, 83). Furthermore, in July 2011, the first South-North Korean high-level meeting held on the sidelines of the ARF helped to defuse some of the tensions from the Cheonan 
incident and the North Korea’s attack on Yeonpyeong Island in 2010.

\section{Policy Implications}

The Six-Party Talks could learn from its own failures as well as other successful case studies to increase its effectiveness and longevity if it were to resume in the future. First, there is a need to closely examine the political motivations and goals of the DPRK. Since walking out of the Six-Party Talks in 2009, Pyongyang has revised its constitution in 2012 to proclaim itself a nuclear state, justifying this proclamation with alleged U.S. hostility and threats to its national security. A pessimistic reading of North Korea's participation in the Six-Party Talks suggests a lack of serious commitment from North Korea to denuclearization on the Korean Peninsula in the first place. Busznyski suggests that Pyongyang became involved only as a result of Chinese pressure and bribery, and it did not have much interest in the Six-Party Talks from the start (Busznyski 2013, 45). Pritchard also explains that the provision of light-water reactors by the United States would not be a deal breaker if Pyongyang were serious about denuclearization, as was claimed (Pritchard 2007, 119). It is possible that the DPRK only agreed to participate in the Six-Party Talks to buy time for their nuclear and missile development program. In fact, North Korea could have approached the talks with the sole intention of bargaining diplomatic and economic benefits with military might. According to such logic, the DPRK representatives would not agree to CVID easily as it means the loss of their only bargaining chip. Instead, North Korea had effectively exploited the presence of great power rivalry and divisiveness among the other members, by resorting to direct intimidation and threats of escalation, to play upon fears and rouse China and Russia to protect it against the United States (Buszynski 2013, 190).

Also, the DPRK prizes its nuclear arsenal as the ultimate security guarantee on top of its sole bargaining chip against its perceived adversaries. As Smith explains, Pyongyang has drawn lessons, especially from the experiences of regime changes in Iraq and Libya, that "nuclear armed states were never attacked by foreign invaders" (Smith 2015, 299). In North Korea’s view, if Muammar Gaddafi had not given up the Libyan nuclear program, his regime would not have fallen (ibid., 300). In addition, the DPRK's nuclear ambitions complement its foremost priority of regime survival. According to Smith, Kim Jong-il's military-first policies were specifically designed to "achieve symbiosis of the interest of the Kim family with those of the military as an institution and to legitimize regime goals through the promotion of a national ideology as well as the continued glorification of the Kim family" (ibid., 236). Given Kim Jong-il's terrible track record on economics, the regime needed a distraction and a scapegoat for its people who have been confronted with widespread poverty. By maintaining a 
siege mentality, the North Korean government could push the blame of North Koreans' suffering onto their perceived foreign adversaries, and the military-first ideology was "portrayed as the only way to guard against the machinations of foreign countries," convincing the people to place the interests of the collective above their own in the decades of limited resources (ibid., 244). Such politics serve the purpose of the Kim regime well, who value regime survival above all else. Most importantly, for Pyongyang, the best military solution to their country's perceived vulnerabilities was not conventional forces, but nuclear weapons. An advanced nuclear arsenal not only fends off potential invasions, but also helps to feed North Koreans' sense of national pride and confidence in the era of hunger and poverty.

It seems that North Korea will continue to pursue its military-first, or Songun, policy in the foreseeable future, especially since a strong military with an impressive nuclear arsenal would lend credibility to the young and relatively inexperienced Kim Jong-un. This means that even if the United States were to offer North Korea an alternative security guarantee, it may not be in the latter's strategic interests to accept the olive branch. Therefore, it is highly unlikely that Pyongyang would ever agree to CVID. If the parties wish to manage the ongoing crisis by resuming negotiations via the Six-Party Talks, they must be prepared to accept the freezing of nuclear development, or limited, gradual rollbacks of the North Korean nuclear program instead of insisting on CVID. In the land of bad policy options, stakeholders have no choice but to pursue the "least bad" path, which is to defuse tensions and halt more nuclear advancement if possible.

At the same time, to increase the success of the Six-Party Talks if it were to resume, there is a need to raise the stakes and opportunity costs for the DPRK. Regional stakeholders can draw lessons from the relative success of multilateral engagement towards Iran. The 2015 Iran Nuclear Deal has seen more success than the Six-Party Talks because the stakes and opportunity costs for Iran were higher. In contrast to the DPRK, the Iranian economy depends heavily on energy exports and would benefit more from the lifting of international sanctions. In fact, oil, gas, chemicals, and petrochemicals made up 75 percent of Iran's total exports in 2014. The impact of the sanctions were severely felt by Iranians: plummeting oil exports and revenues, eroding currency values, businesses shuttering due to trade disruptions, and a high inflation rate (Maloney 2014). Moreover, Tehran also encourages foreign investments and trade, and the government faces "significant pressure from its people to end its decades of international isolation" (Tan 2016). In 2013, Iranian voters elected a moderate new president, Hassan Rouhani, who had "an explicit mandate to resolve the nuclear issue and improve the economy" (Maloney 2014). In contrast, North Korea is more autarkic, celebrates its Juche or self-reliance ideology and its self-imposed isolationism, holds a notorious record for its systematic repression of its people, and is much less dependent on foreign trade and access to the international financial system. Furthermore, unlike 
Pyongyang who has already developed several nuclear weapons in its arsenal, Iran did not have sufficient fissile material stockpiles to create a nuclear weapon at the time of the negotiation.

To raise the stakes and opportunity costs for the DPRK, the stakeholders can target the sustainability of its economy by imposing even tougher sanctions. Kim Jong-un has adopted a policy known as the "Byungjin Line" which refers to the simultaneous pursuit of economic development and deterrence through a nuclear program, inspired by both Juche and Songun. However, this dualtrack policy would not be sustainable in the long-run if the resources that are required for economic development continue to be directed away and allocated to the nuclear program instead. Imposing tougher sanctions on North Korea and blocking its access to external resources may persuade the leaders in Pyongyang that their nuclear ambitions may prove harmful for regime survival, which is their top priority. To significantly increase the stakes and opportunity costs for the DPRK, however, China needs to prioritize denuclearization or limitation of the North Korean nuclear program over the stability of the North Korean regime. The cooperation of China in imposing tougher sanctions is critical as it is the only Six-Party Talks member who still wields a certain degree of influence over the DPRK. In fact, the DPRK is almost completely economically dependent on China, who has been North Korea's biggest trading partner and it also supplies most of its food and energy. In 2015, Chinese trade accounted for 75.8 percent of North Korean exports and 76.4 percent of its imports (Central Intelligence Agency 2016).

In addition, for a resumption of the Six-Party Talks to be meaningful, full cooperation and agreement on policy priorities between all participants is paramount. Firstly, the United States, China, Russia, Japan, and South Korea need to resolve their differences at the multilateral level. The five states should coordinate their five different sets of bilateral relations with Pyongyang and agree on common goals and incentives before any multilateral effort can be fruitful (Kim and Kang 2009, 11). This may be challenging, as Japan's relations with China and South Korea have been chilly due to their contested and unresolved historical issues, on top of existing territorial disputes. Even so, the revival of the Trilateral Summit between the three neighbors in November 2015 has led to some hope for the situation. In fact, the resumption of the Six-Party Talks and the denuclearization of North Korea were placed on top of the summit's security agenda. Moreover, Kim Jong-un's execution of his uncle Jang Song-thaek, who was regarded as pro-Beijing, in 2013, combined with the DPRK's testing of a long-range rocket on the eve of Chinese New Year in 2016 despite Beijing's dissuasion, have heightened Chinese annoyance and concerns over North Korean unpredictability and recklessness. Hence, it is possible that Beijing would be more willing to employ tougher measures towards the DPRK. 


\section{Discussion}

Overall, this article has discussed both the Six-Party Talks and the ASEAN Regional Forum individually and comparatively. Both multilateral efforts have their own strengths and weaknesses. If regional stakeholders overcome the obstacles of strategic interest misalignment, agree on policy priorities, and raise the stakes and opportunity costs for the DPRK, the Six-Party Talks has better structural potential to deal with the nuclear crisis than the ARF. At best, the latter can take a complementary, but secondary, role to ease tensions and improve relations as it adopts a non-confrontational approach to engagement.

Due to the lack of meaningful progress from both institutions thus far, it may be useful to consider alternative solutions which can also be complementary to the existing multilateral engagement efforts. In addition to multilateral approaches, the United States has relied heavily on military deterrence, stressing the importance of its bilateral security alliances with Japan and South Korea. Having a credible deterrent against the DPRK continues to be pertinent. It was announced in May 2017 that the Terminal High Altitude Area Defense (THAAD) system in Seongju, South Korea was finally deployed and operational. Regardless of China's protests and suspicions, the United States and South Korea should press on with their decision given the volatility of the DPRK regime and its series of provocative actions in recent months.

Additionally, Hyeran Jo and Jongryn Mo make a case for U.S.-JapanKorea trilateralism in addressing the North Korea issue (Jo and Mo 2015, 6799). They opine that trilateralism can contribute to the resolution of the nuclear problem by reviving the Trilateral Coordination and Oversight Group (TCOG) to complement other multilateral solutions as the TCOG improved coordination between Washington, Tokyo, and Seoul during its active years between 1999 and 2002 (ibid.). Trilateralism seems more likely to succeed than U.S.-China bilateralism due to the two great powers' competition for influence in the region in recent years. On top of that, this approach can help to facilitate a larger cooperative framework for Asian regional security in the long-term if they can exercise effective leadership in institutions such as the ARF (ibid.).

Finally, it might be prudent for ASEAN to play a bigger role in the mitigation of the nuclear crisis. The nuclear quagmire on the Korean Peninsula constitutes a global, not just regional, threat, as it is possible that Pyongyang may export its nuclear know-how and materials to other rogue states and terrorist organizations. Southeast Asia and the rest of the Asia Pacific will also be negatively affected if a nuclear arms race were to occur in Northeast Asia. North Korea's regular attendance of ARF meetings points to ASEAN's potential to become more active in its contribution to denuclearization of the Korean Peninsula, even if it is indirect. The ASEAN way of non-interference and consensus appeals to the authoritarian DPRK and is typically seen as less threatening to regimes with a 
siege mentality. Thus, ASEAN seems well suited to serve as a neutral mediator who can help facilitate negotiations and monitor progress to increase the sustainability of engagement efforts, especially if the various stakeholders seek a new issues-focused and purpose-driven multilateral platform outside the SixParty Talks and the ARF. Er-Win Tan, Geetha Govindasamy, and Chang Kyoo Park also highlight how ASEAN can help to promote North Korean economic reform, capacity building, and eventual integration into the international community (Tan et al. 2015, 1-16). The DPRK has shown increasing interest in adapting the experiences of ASEAN members' economic reforms and development; especially that of Singapore who employed a top-down approach, and of Vietnam who shares its communist ideology (ibid.).

Generally, it seems that any real reforms or concessions from North Korea need to come from within the country itself as Pyongyang is seen to be very resistant towards external pressures. In the meantime, it is pertinent for the United States, Japan, and South Korea to continue to maintain effective and credible military deterrence vis-à-vis North Korea. Nevertheless, this does not mean that they should give up on efforts to engage and negotiate with North Korea. Due to the DPRK's tendencies to make unpredictable moves, it remains necessary for the region to understand North Korea's interests in order to formulate appropriate responses and contingency plans, rather than allowing it to be dangerously isolated. Therefore, a balance between military defense and multilateral engagement seems to form the most effective policy option to manage the North Korean nuclear problem at the present, even if this may not resolve the crisis completely.

\section{References}

ASEAN (Association of Southeast Asian Nations) Regional Forum. 2007. Documents Series 1994-2006. Jakarta: The ASEAN Secretariat.

ASEAN (Association of Southeast Asian Nations) Regional Forum. 2010a. Documents Series 2006-2009. Jakarta: The ASEAN Secretariat.

ASEAN (Association of Southeast Asian Nations) Regional Forum. 2010b. "Chairman's Statement of Seventeenth ASEAN Regional Forum, Hanoi, Viet Nam, 23 July 2010." http://aseanregionalforum.asean.org/files/library/ARF\%20Chairman's\%20 Statements\%20and\%20Reports/The\%20Seventeenth\%20ASEAN\%20Regional\%20 Forum,\%202009-2010/ARF\%2017\%20Chairmans\%20Statement\%20-\%20Final\%20 (rev.\%20on\%20title\%20year).pdf (accessed October 27, 2016).

Ashizawa, Kuniko P. 2004. "Japan, The United States, and Multilateral InstitutionBuilding in the Asia-Pacific." In Beyond Bilateralism: U.S.-Japan Relations in the New Asia-Pacific, eds. Ellis S. Krauss and T.J. Pempel, 248-271. Stanford, CA: Stanford University Press.

Bae, Jung Ho, and Sung Chull Kim. 2009. “Japan’s North Korea Policy: The Dilemma of 
Coercion.” In Engagement with North Korea: A Viable Alternative, eds. Sung Chull Kim and David C. Kang, 73-98. New York: State University of New York Press.

Buszynski, Leszek. 2013. Negotiating with North Korea: The Six Party Talks and the Nuclear Issue. Abingdong, Oxon: Routledge.

Cha, Victor D., and David C. Kang. 2003. Nuclear North Korea: A Debate on Engagement Strategies. New York: Columbia University Press.

Choi, Jong Kun. 2016. “The Perils of Strategic Patience with North Korea." The Washington Quarterly 38 (4): 57-72.

Fuqua, Jacques L. Jr. 2007. Nuclear Endgame: The Need for Engagement with North Korea. Westport, CT: Praeger Security International.

Glosserman, Brad. 2010. "The United States and the ASEAN Regional Forum: A Delicate Balancing Act." In Cooperative Security in the Asia-Pacific: The ASEAN Regional Forum, eds. Jürgen Haacke and Noel M. Morada, 36-53. Abingdon, Oxon: Routledge.

Green, Michael. 2016. “'Strategic Patience’ With North Korea Gets You Nowhere." Foreign Policy, January 7. http://foreignpolicy.com/2016/01/07/strategic-patience-with-northkorea-gets-you-nowhere/ 2/12 (accessed May 27, 2016).

Gui, Yongtao. 2013. "Major powers' policies towards North Korea and Implications on Sino-Japanese Relations." In Sino-Japanese Relations: Rival or Partners in Regional Cooperation, eds. Niklas Swanström and Ryosei Kokubun, 105-128. Singapore: World Scientific Publishing Company.

Hughes, Christopher R. 2010. "China's Membership of the ARF and the Emergence of an East Asian Diplomatic and Security Culture." In Cooperative Security in the AsiaPacific, eds. Jürgen Haacke and Noel M. Morada, 54-71. Abingdon, Oxon: Routledge.

Jo, Hyeran, and Jongryn Mo. 2010. "Does the United States Need a New East Asian Anchor?: The Case for U.S.-Japan-Korea Trilateralism.” Asia Policy 9: 67-99.

Kahn, Joseph. 2002. "North Korea Says It Will Abandon Nuclear Efforts." New York Times, September 30. http://www.nytimes.com/2005/09/19/international/asia/19korea. html?_r=0 (accessed January 3, 2015).

Katsumata, Hiro. 2009. ASEAN's Cooperative Security Enterprise: Norms and Interests in the ASEAN Regional Forum. Basingstoke: Palgrave Macmillan.

Keohane, Robert O. 1990. “Multilateralism: An Agenda for Research.” International Journal 45 (4): 731-764.

Kim, Sung Chull, and David C. Kang. 2009. "Introduction: Engagement as a Viable Alternative to Coercion." In Engagement with North Korea: A Viable Alternative, eds. Sung Chull Kim and David C. Kang, 1-22. New York: State University of New York Press.

Kwak, Tae-Hwan. 2014. "The Denuclearization of the Korea Peninsula through the SixParty Talks." In North Korea and Security Cooperation in Northeast Asia, eds. TaeHwan Kwak and Seung-Ho Joo, 9-30. Surrey: Ashgate Publishing Limited.

Kwak, Tae-Hwan, and Seung-Ho Joo. 2007. "Introduction." In North Korea's Second Nuclear Crisis and Northeast Asian Security, eds. Seung-Ho Joo and Tae-Hwan Kwak, 1-13. Hampshire: Ashgate Publishing Limited.

Lake, Anthony. 1994. "Confronting Backlash States." Foreign Affairs 73 (2): 45-55.

Maloney, Suzanne. 2014. "Why 'Iran Style' Sanctions Worked Against Tehran (And Why They Might Not Succeed with Moscow)." Brookings, March 21. https://www. brookings.edu/blog/markaz/2014/03/21/why-iran-style-sanctions-worked-againsttehran-and-why-they-might-not-succeed-with-moscow/ (accessed Oct 27, 2016). 
Moon, Chung-in. 2013. “The Six Party Talks and Implications of Peninsular and Regional Peace and Security." In Korea and East Asia: The Stony Road to Collective Security, eds. Rüdiger Frank and John Swenson-Wright, 217-239. Leiden: Koninklijke Bril NV.

Paik, Haksoon. 2013. "North Korea's Place in East Asian International Relations." In Korea and East Asia: The Stony Road to Collective Security, eds. Rüdiger Frank and John Swenson-Wright, 181-216. Leiden: Koninklijke Bril NV.

Pritchard, Charles L. 2007. Failed Diplomacy: The Tragic Story of How North Korea Got the Bomb. Washington, D.C: The Brookings Institutions.

Severino, Rodolfo C. 2009. The ASEAN Regional Forum. Singapore: Institute of Southeast Asian Studies.

Smith, Hazel. 2015. North Korea: Markets and Military Rule. Cambridge: Cambridge University Press.

Solingen, Etel. 2005. "East Asian Regional Institutions: Characteristics, Sources, Distinctiveness." In Remapping East Asia: The Construction of a Region, ed. T.J. Pempel, 31-53. Ithaca, NY: Cornell University Press.

Tan, Er-Win, Geetha Govindasamy, and Chang Kyoo Park. 2015. "The Potential Role of South-East Asia in North Korea's Economic Reforms: The Cases of ASEAN, Vietnam and Singapore." Journal of Asian and African Studies 5: 1-16.

Tan, Ming Hui. 2016. "Resuming the Six-Party Talks?: Bleak Prospects." RSIS Commentary. https://www.rsis.edu.sg/rsis-publication/cms/co16040-resuming-the-six-party-talksbleak-prospects/\#.WYgic1GrSUk (accessed October 27, 2016).

Yamamoto, Yoshinobu. 2008. "Institutionalization in Northeast Asia: Is Outside-in Regionalization Enough?” In Institutionalizing Northeast Asia: Regional Steps Towards Global Governance, eds. Martina Timmermann and Jitsuo Tsuchiyama, 21-42. Tokyo: United Nations University Press.

Yoo, Jee-ho. 2010. "South Korea comes away with a partial victory at ARF." Yonhap News Agency, July 10.

Yuzawa, Takeshi. 2005. “Japan's Changing Conception of the ASEAN Regional Forum: From an Optimistic Liberal to a Pessimistic Realist Perspective." Pacific Review 18 (4): 463-497.

Yuzawa, Takeshi. 2007. Japan's Security Policy and the ASEAN Regional Forum: The Search for Multilateral Security in the Asia-Pacific. London and New York: Routledge.

Yuzawa, Takeshi. 2010. "Japan and the ASEAN Regional Forum: From Enthusiasm to Disappointment." In Cooperative Security in the Asia-Pacific, eds. Jürgen Haacke and Noel M. Morada, 72-91. Abingdon, Oxon: Routledge.

\footnotetext{
Ming Hui Tan is an Associate Research Fellow at the S. Rajaratnam School of International Studies (RSIS), Nanyang Technological University. Her research interests include Japan's foreign policy and the international relations of East Asia. She obtained her Master's Degree in International Relations from RSIS and her Bachelor's Degree in Japanese Studies from the National University of Singapore.
} 